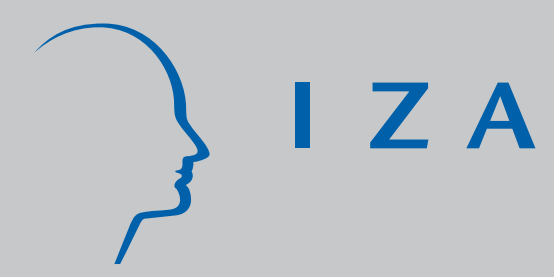

IZA DP No. 1001

Advising Policymakers Through the Media

Klaus F. Zimmermann

J anuary 2004 


\title{
Advising Policymakers Through the Media
}

\author{
Klaus F. Zimmermann \\ IZA Bonn, University of Bonn \\ and DIW Berlin
}

\section{Discussion Paper No. 1001 January 2004}

\author{
IZA \\ P.O. Box 7240 \\ 53072 Bonn \\ Germany \\ Phone: +49-228-3894-0 \\ Fax: +49-228-3894-180 \\ Email: iza@iza.org
}

\begin{abstract}
Any opinions expressed here are those of the author(s) and not those of the institute. Research disseminated by IZA may include views on policy, but the institute itself takes no institutional policy positions.

The Institute for the Study of Labor (IZA) in Bonn is a local and virtual international research center and a place of communication between science, politics and business. IZA is an independent nonprofit company supported by Deutsche Post World Net. The center is associated with the University of Bonn and offers a stimulating research environment through its research networks, research support, and visitors and doctoral programs. IZA engages in (i) original and internationally competitive research in all fields of labor economics, (ii) development of policy concepts, and (iii) dissemination of research results and concepts to the interested public.
\end{abstract}

IZA Discussion Papers often represent preliminary work and are circulated to encourage discussion. Citation of such a paper should account for its provisional character. A revised version may be available on the IZA website (www.iza.org) or directly from the author. 
IZA Discussion Paper No. 1001

January 2004

\section{ABSTRACT}

\section{Advising Policymakers Through the Media*}

In the information age an exchange with the media is part of the duties the economics profession has to deliver to educate the public and to ensure its position in society. A key issue is the education of policymakers through the media. It is the silver bullet of policy advice in comparison to commissioned research and face-to-face advice provided to the politician. It also pleases the vanity of the scientist: Few economists are willing to sacrifice the celebrity of public visibility to the effectiveness of face-to-face advice. The paper advertises for a stronger role of researchers in the public debate and suggests ways to become more influential. It is argued that in the long run agenda setting is a more promising strategy than reactive press activities.

JEL Classification: A11, A20

Keywords: media activities, policy advice, educating the public, journalism

Klaus F. Zimmermann

IZA

P.O.Box 7240

53072 Bonn

Germany

Tel.: +492283894200

Fax: +492283894210

E-mail: zimmermann@iza.org

\footnotetext{
"Invited contribution to the session on "Economic Education and Journalism" at the San Diego ASSA Meetings, January 2-4, 2004. I thank Markus Braig, Michael Burda, Amelie Constant, Henk Don, Mark Fallak, Bruno S. Frey, Dan Hamermesh, Holger Hinte, Norbert Hoekstra, Dörthe Höppner, Michael Mandel, Margard Ody, Hilmar Schneider, Paul Solman, Gert G. Wagner and Charles Wyplosz for helpful comments on previous drafts.
} 


\section{$\underline{\text { 1. Introduction }}$}

Most economists believe that they understand better than anyone else how the economy works. But as soon as they leave their offices or the seminar room, their expertise is of low value. The man on the street does not really understand economics - and never will. Politicians are mirrors of society. They do not want to understand economics, even if they could. The logic of power and the logic of economics are usually irreconcilable. This does not mean that politics and the public debate do not follow the laws of economics. But complex results must be translated into simple messages. Economists are used to think in hyperplanes and n-dimensional quadrants. Politicians and the public, however, think uni-dimensional. Paul Krugman once told me that the key mission of economists should be to teach about the existence of identities.

As an educator of the nation, the economist has to complete a Herculean task. Driven by pride, self-confidence, and egocentrism, he wants to tell policymakers and the public what needs to be done. In practice, he will soon become frustrated because people do not understand him or even worse, they do not listen to him. Few economists decide to become active in politics. Most of them return to their ivory tower sooner or later. Some betray their science and turn into public opinion brokers. Very few succeed in reconciling both worlds - shaping public opinion while remaining active in doing research. Hence, the "market" for media exposure is in trouble: Supply and demand hardly match, since the media tend to look for provocative headlines, controversial opinions, anything counter to official positions and the like.

The ethics of economics as a science includes the responsibility to provide information for the public. This duty, however, is not taught at universities and rarely put into practice. My contribution is therefore meant to advertise this responsibility and to suggest ways for better implementation. I will focus on the role that economists can play in shaping politics. It is my contention that communication and a pact with the media are the most promising ways to provide effective policy advice. The unforgotten Rudi Dornbusch of MIT once told a journalist, 
"I advise nations, not governments." I will develop this position against the background of expertise with the European and especially the German media.

First of all, I will explain what drives economists to go to the public arena, and how they become media stars. I will then examine the production process of policy advice and the interaction with the public. I will also take a closer look at the channels of cooperation among economists, politicians, and the media. Finally, I will evaluate the prospects of economists as educators of the nation.

\section{Why do economists advise policy makers and how do they become media stars?}

I receive several requests by the media every day. They are filtered and channeled by two press officers and two personal secretaries in two different cities. Most requests are turned down. After all, selection is the key to successful press work facing a tight schedule. Since 2000, I have been commuting back and forth between IZA (Institute for the Study of Labor) in Bonn, where I am also a tenured professor at Bonn University, and DIW Berlin (German Institute for Economic Research). IZA is a private research institute financed by Deutsche Post World Net. While it is an independent organization, IZA maintains close ties to the University of Bonn. As the director of this internationally oriented labor market institute, I organize academic research and ensure its successful dissemination to a wider public. As the president of DIW Berlin, I head the largest German think tank in economics, which is financed in half by research funds from the government. The other half is derived from policy advice projects for governments and international organizations. In addition to academic research, management tasks and policy advice, communication with the media is an important part of my job.

I assumed my role as an "object of the media" rather late and more or less by accident. To be honest, I had always been interested in the media. For instance, I edited my high school newspaper and later worked as a press officer for a political organization. I decided to study economics because I regarded this discipline as the perfect foundation for a job in the societal 
sector. However, I ended up getting caught by the fascination of fundamental research, which led me towards a career as a university professor. It was Richard Portes who eventually convinced me that research should and must be oriented towards politics and the media. His Centre for Economic Policy Research (CEPR) in London has had and continues to have a significant impact on the development of economics as an empirical and policy-relevant discipline in Europe. As Programme Director for Labour Economics I served the CEPR for more than a decade. The communication of research findings to the general public was part of my job, which I learned to do with support from the CEPR.

Nonetheless, my background was doing internationally competitive research, and I had little experience with policy advice and the media when I became Director of IZA in 1998 and additionally President of DIW Berlin in 2000. Since I did not have much time to systematically train for media tasks in the following years, most of it was learning by doing. What I enjoy most of all is writing op-ed and viewpoint articles, which I do several times a month. In the beginning a single article would often take me days to write - now it is usually a few hours. (We do our best when we face the toughest challenges - work under pressure can be stimulating.) You can read newspaper articles over and over again, or show them around, and they are closer to academic work than other media activities. Newspaper interviews are very influential, but you need to ensure proper editing, or else you will soon be in trouble. Since the radio is a medium of limited reach for my purposes, I tend to ignore it. Television newscasts and talk shows are influential even if most of what can be conveyed to the general public via these means is rather profane. Television requires a smooth, relaxed appearance, and the "how" tends to outweigh the "what".

Today economists certainly have a much larger impact on public opinion in Europe than they had ten years ago. Organizations like the CEPR, but also a number of national institutional developments have contributed to this trend. The foundation and development of the European Economic Association and the reform of national economics societies have created a broad basis 
for policy-oriented economic research, thus strengthening the potential for communication with the media. Germany has seen a massive increase in academic competition due to reforms of the Verein für Socialpolitik, the German Economic Association, and the enhancement of academic research as a prerequisite for public funding of research institutes.

The more prominent position of economists in the public, at least in Germany, is also reflected by their growing willingness to publicly interfere with the political process. A good example of this trend is the memorandum by 300 university professors, who have publicly urged the German government in the summer of 2003 to implement consistent and radical reforms. The reform debate is documented in Zimmermann (2003). This book also contains the visions of some top German economists for further reform steps over the next years, on which economists should have an influence. The critical assessment by Wyplosz (1999) of leading German economists' policy advice and media activities therefore needs some substantial revising today.

The interference with the political process, the role of an educator of the nation, and thus the crossing of the borders of the scientific profession is justifiable only if economists are certain that they have sufficient knowledge, sensitivity for the matter, a certain diction, and a potential political influence. You need to be a sharp communicator and media savvy. What motivates economists to play a larger role as educators of the nation, as policy advisers, and as instructors of the public? Economists who work for public organizations have a societal obligation to educate the public, which they often fail to fulfill adequately. But media appearances can also be exciting and fun, they can help to enhance one's own knowledge of specific research topics, and they generate additional income. Paul Samuelson's position - "I don't care who writes a nation's laws if I can write its economics textbooks" - is less critical than it reads: The economist does not have to turn into a politician, but he should better utilize the tools of a media society to fulfill his educational obligation - an obligation which, by the way, Paul Samuelson has more than satisfied through his popular textbooks and his media activities. By writing textbooks and educating the public, economists will ultimately write the laws of the nation in an indirect way. 
Furthermore, in times of decreasing financial resources it is certainly a sound strategy to convince your "customers" in society that you are doing an important job. What better way to do this than through the media?

The impact of media activities on one's own reputation within the profession is ambiguous. Those who are present in the media are certainly well perceived by colleagues if they promote the image of the profession. But media activities also give rise to the suspicion that the economist in question no longer conducts original research. I personally consider media presence very important for the economist's profession. But to ensure quality and scientific acceptance, a twofold obligation towards policy advice and research is necessary. I encourage especially those economists who are actively engaged in research activities to enter the public debate more often. It is not at all a waste of talent of the smartest heads, but a useful investment in the good will of society.

The debate about the unknown or insufficient influence of economists has a long tradition. But is it justified? A profession can only be represented successfully if it is founded on a broad consensus. Despite all the jokes to the contrary, there is some evidence that the consensus between economists is rather large (Alston, Kearl, and Vaughan, 1992; Frey, 2000 und 2003), even if opinions on the effectiveness of certain political programs may diverge more strongly (Fuchs, Krueger und Poterba, 1997). Blendon et al. (1997) report that there is a substantial discrepancy between how the public and the economists view the economy. To close this gap by active advice or education is also a task of research policy: Either the economists are wrong - then we have a reason to revise our theories. Or we are right - then we have not yet succeeded in presenting economic matters and their consequences across to the public.

Do we as economists represent a successful discipline, especially in advising policymakers and the public? The Economist $(1997,2000)$ and other external observers from the press (Weinstein, 1992) deliver a rather negative assessment. Schelling (1997) sees the solution of simple problems as the main contribution by economics, but he also demonstrates a large 
potential for policy advice in many different subdisciplines. Wyplosz (1999) and Frey (2000, 2003) assess the impact of economists rather positively, and they attribute it to the active role of leading economists in politics and policy advising. This, however, applies more to the United States than to Europe. Although there are many impressive examples of personal success stories of individual economists, a methodologically satisfying measurement of economists' impact does not yet exist.

\section{The practice of policy advice and the role of the media}

The relations between economists and politicians are complex. For example, Rivlin (1987, p.1) writes: "Economists and political leaders not only miscommunicate, but each accuses the other of incompetence, obfuscation, self-serving motives, and anti-social behavior.” In Germany, there are also often tensions between economists and the political class. Concentrating largely on fundamental research, academic science in Germany is politically rather abstinent. At the same time, policymakers across party lines and at all levels of decision making are quite resistant against scientific advice. They are primarily interested in timely support for their upcoming actions. In between, there are traditionally such policy advice institutions as the German Council of Economic Experts, scientific advisory boards to the federal ministries, and the research institutes. They all provide policy advice from an external, independent position.

Such a system has strengths and weaknesses. It happens that an economist declines offers to join an expert council or to head a research institute because his word supposedly will not be heard in political practice. For instance, with a lot of media attention, Michael Burda of Humboldt University, Berlin, recently not only declined a seat on the German Council of Economic Experts but also the presidency of the Kiel Institute for World Economics. He stated that, given the insufficient direct influence of these positions on policymaking, he would prefer to continue his academic research. At the same time he has increased his media activities. 
Policymakers retort that most advisory councils present unrealistic proposals, fail to satisfy the needs of policymaking, and take too long to come up with well-founded recipes. According to a German government official, who spoke at the annual congress of the Verein für Socialpolitik 2003 in Zurich, private consultants and ad hoc committees with representatives from academia and society are the preferred way to solve urgent problems. In his view, private consultants are expected to replace more and more academic economists in the business of policy advice. However, recent public discussions about the success of private consultants in acquiring projects from the government have pointed at the high costs and the debatable quality of some of these activities. Academic scientists typically are not only less expensive but also more knowledgeable in economics than consultants. If not taken seriously by the policymakers, they can provide their critical evaluations to the media. It is then in the interest of the policymakers to involve academic economists more often and much earlier in the political process to gain the support of science.

The accusation that academic science fails to work on a short-term horizon is severe but misguided. Scientists must think over the longer term. Visions are needed to develop permanent solutions to the key social problems. There is a misunderstanding among policymakers about the nature of economics as a science and its potential usefulness for policy. This is an idea of politics that can no longer be sustained in the age of globalization: Problems are only treated when absolutely necessary. Since quick change is required, reforms are continuously implemented in small steps. Once the house is flooded, the plumbers are called. But with the help of an architect, the entire problem may have been avoidable.

A good example of politicians' ignorance towards problems is demographic change in Germany. Its consequences for family formation, labor markets, social security systems and migration have been intensively discussed among economists since the early 1970s. Policyrelevant contributions fill entire libraries. There is no lack of concepts nor of visions. Nonetheless, problems like pension funding were treated in such small steps that the solutions 
hardly last until the next elections. This may be due to our consensus democracy, lobbyism, or the blocking powers of the Bundesrat, the upper chamber of the parliament. But it is certainly not due to a lack of concepts provided by scientists.

It is true that thinkers are rarely good handymen. But this does not rule out that researchers can make helpful contributions to the solution of urgent problems. They can operate externally, outside of the sphere of the policymaker, in an independent body of experts, or internally, as part of the government or an appointed committee to study a particular issue. Since the topics discussed and the instruments suggested are closer to the interests of policymakers for the internal advisor, she has a higher potential to be more influential.

Several reform commissions in Germany have recently proven the point. What Germany still needs, however, is more of internal advice by scientists like it is organized in the case of the Council of Economic Advisors in the United States. The council is part of the government and consists of economists who are trusted by the political leadership and who work for the administration as long as the existing political and academic visions can be reconciled. This type of internal advice often goes unnoticed by the public, which makes it even more effective in dayto-day business.

Legislators in Germany have largely constructed external and independent institutions for the purpose of policy advice. Media attendance and the publication of research findings and policy proposals are important to strengthen the independence of the policy advisor. This also creates a critical distance to the details of day-to-day policy and leads scientists to question matters of policymaking and to call for improvements. Much of the effectiveness of external advice results from communication with the public, which is an essential part of the advice package. The scientist as a political advisor has an important educational task with regard to basic economic matters. However, external advisers have their own criteria for agenda setting according to political necessities. Scientists are more interested in the establishment of solutions that have a long-term impact on the economy. This includes demands for a scientifically 
convincing evaluation of government programs, the implementation of social experiments to determine future programs, and the delegation of political power to bodies of experts with the necessary competence in economic matters. We need more, not less, of this kind of sustainable economic policy with solutions that will hold in the long run.

There are several positive signs indicating that the communication between research and policymaking is improving. As an example, the book "Frontiers in Economics" (Zimmermann, 2002) resulted from the German government's desire to acquire comprehensive information on new developments in the subdisciplines of economics, which have a potential impact on the making of economic policy. In this project, the entire structures of economic policy advice in Germany were also evaluated. The study was carried out by academics from several research institutes and various universities.

For economic policy advice in Europe and in Germany in particular, researchers from universities are traditionally less important than those working for research institutes. The appendix provides a table with an overview of the European institutes in terms of staff and budget size. The German institutes (with the exception of IZA, which is privately funded) receive basic funding from the government. They are evaluated by their own scientific advisory boards and by independent external committees on a regular basis. Their task is to provide original research and policy advice and to communicate their findings through publications as well as through the participation in academic and societal discussions. This explicitly includes communication with the media. German legislators thus wanted a competition for the best ideas on policy-relevant research.

The role of academic research at the institutes has gained significance over the past few years. For instance, presidency positions have only been awarded to internationally renowned academics. The publications output in refereed journals is growing rapidly. Networking between research institutes and universities has substantially improved the academic quality. At DIW Berlin, with 214 employees the largest German think tank of this kind, all seven department 
heads hold professorships at universities. They are also required to present their research findings and policy advice to the media. The ultimate goal of the reforms that have been ongoing for a few years is to strengthen academic research and policy advice while improving the promotion and public reception of these findings.

Policy advice takes place via three channels: (1) Commissioned research, which is paid for by the contracting authority and usually results in the delivery of a report or an expert opinion, (2) face-to-face advice given to a politician, usually in a confidential manner, in the form of a background dialogue, and (3) indirect policy advice via the media. In practice, these channels are of course interlinked in many ways. For commissioned research in Germany, the institutes are legally required to publish the final reports. This is usually combined with a press conference, a press release, or the publication of a didactic article with further advertisement for the research results. Thus the contribution cannot be lost in the apparatus, but its impact will be reinforced through the information of the public.

If an economist does not have access to a politician through his own political orientation, the access opportunities will be largely defined by his public visibility and trustworthyness. His opportunities will be improved by his media presence rather than by his professional expertise and standing. Another requirement for an easy access to the politician is that the scientist can be trusted to provide advice discretely and she will not oppose the politician fundamentally in the public. To be realistic, few economists are willing to sacrifice celebrity to effectiveness.

Given that European and German policymakers are hesitant to proactively seek advice, the media channel is of central importance. In my view it is the silver bullet of policy advice. As Wyplosz (1999, p. 67) puts it: "It has many advantages: it reduces the risk of compromising; it is less time-consuming; it limits accountability; it offers more visibility. It may also be efficient, given the weight of media in modern open societies." Politicians and their advisory machinery, as well as decision makers in political parties and associations turn to the media to obtain information on current scientific research. Concepts presented in the media often become 
separated from their scientific promoters; they become self-contained and gain creative power. What could be a better achievement for a researcher than his policy concept being proposed to politicians by their political support staff?

But the media are not just an important multiplier; they also serve as a translator. This is all the more important as long as we are unable to make ourselves more comprehensible. And as the world is becoming increasingly complex, people are longing for simple explanations and expect advice. Experts that help them cope with this world and make assessments are welcome. It is a widespread perception that politicians just talk, they often lack credibility, and they only care for their own interests. Economists, on the other hand, can provide people with orientation. Journalists are aware of this and can become partners in our advisory and educational task. As a consequence, economists advise politicians as well as "the people".

But politicians are afraid that economists will rival them as media stars, and they hate to be criticized in public. This is why politicians often publicly put down individual economists or the entire profession. Interaction via the media therefore requires a good instinct, courage, and steadfastness on the economist's part.

Steadfastness is also required in the face of the potential reactions of the public to the media presence of the economist. Very often the reactions in letters, phone calls and emails will not be positive, but critical and sometimes even offensive and threatening. Colleagues and the own staff are often not supportive either, because they may think differently or complain to you about a too simplified view. It is likely that a pro-immigration stance causes negative responses from the right, or your support of welfare reforms creates opposition from the left. In the early morning hours of the New Year 2004, a well-known left-wing terrorist group launched a fire attack on DIW Berlin. A letter of acknowledgement on the committed act to the press justified this crime against the institute on the grounds of the strong support by the DIW President and his institutes (IZA and DIW Berlin) for the process of economic reforms in Germany. 


\section{How to interact with the media}

A large part of DIW Berlin's mission in policy advice is carried out through the media. Measured activities include cites and contributions, one-to-one interviews and news statements as well as TV and radio appearances. Overall there is an unequal distribution of press activities across DIW Berlin. Although at least four out of seven departments focus on microeconomic issues, communication with the media is dominated by macroeconomic topics. The findings suggest that public visibility of DIW Berlin is largely dominated by the Department of Macro Analysis and Forecasting. It is responsible for about $44 \%$ of all measured activities. Next ranks the President with $29 \%$ of all measured activities, while the other units of DIW Berlin are somewhat less visible. One-to-one interviews in print media and guest commentaries are dominated by the President, and talk show and TV appearances are largely carried out by the Department of Macro Analysis and Forecasting.

The dominance of macro issues tends to hold for the entire media coverage in Germany, and I have noticed the same structure abroad, for instance during 2003 when I was chairing the external scientific evaluation committee of the CPB Netherlands Bureau for Economic Policy Analysis. Varian (2003) reports similar results for the United States. It appears to be easier for an economist to attract media attention for macroeconomic topics. The media are especially fond of macro forecasts, which they often present in short intervals. Microeconomic analyses, on the other hand, are generally more difficult to convey to the public at an appropriate analytical level.

The dominant role of macroeconomics in the public is not well understood. Some people argue that macroeconomics is easier to understand. Others think that it deals more with issues that have substantial financial impacts, like the forecasts of the stock markets, exchange rates and the business cycle. However, forecasting is a very difficult issue. The problem is that we often do not know enough to predict turning points, which is what the media want us to do. The classroom joke is that macroeconomics deals with the same questions every year, but the answers are different. Microeconomics has different questions every year, but the answers are 
always the same. From this perspective, there should be a chance to use microeconomics more often in the public.

Although there are no general measurements of economists' media presence, MedienTenor does provide a regular independent assessment of the visibility of research institutes, which are responsible for most of the media activities. MedienTenor (2003b) shows that DIW Berlin and the Ifo Institute in Munich are the key institutions in terms of media coverage in Germany. None of the other institutes, with the exception of the Kiel Institute for World Economics (IfW), play a relevant role. For the direct comparison of DIW Berlin and Ifo, it is important to consider that the Ifo coverage is dominated by the Ifo business cycle indicator. When it comes to opinionforming contributions, the introduction of topics for discussion, articles in weeklies, or television appearances, DIW Berlin is even further ahead. The DIW analysis is requested more often than the Ifo analysis (Medien Tenor, 2003a, p. 53). This shows that the measurement of media effectiveness depends on the desired focus. Television or printed mass media are inadequate for conveying truly profound messages. Viewpoint articles in the business press must be well differentiated in order to achieve special attention or educational effects.

What are the lessons to be learned when dealing with the press? This is a small selection of items that I find useful:

1. Economists should refer to common, well proven results wherever possible. Models are important to organize and structure our thoughts. But it is not advisable to advertise them in the communication with the public, since they are typically too abstract to be accepted as images of the real world. It is also problematic to draw general conclusions for the world from small, specific models. Though heavy disputes over marginal problems may be found honorable within the profession, they discredit the discipline as such. It is an important goal to inform the media, the public and policymakers about important basic matters in economics. One should talk about findings that are in good textbooks, because they are then sufficiently well established to be made available for public consumption. 
2. Agenda setting is the premier league of media activity. This is where the economist himself determines the topic for discussion. It is often a single book, a research report or a regular academic paper that is appropriate to be conveyed to the public. Economists should preferably talk about matters that lie within their own field of expertise. Nothing is better suited than the economist's own current research. Viewpoint articles, a comprehensible press release, or a press interview are adequate tools to get the message across. You do not need a Nobel Prize to successively build up useful press contacts. If you belong to a media-oriented institution, chances are that you will find good help within.

3. Reactive press activity is the devil's work. If you are willing to talk to anyone about anything, you are likely to become a highly sought-after individual soon. But there is a danger that flawed information and uninformed commentaries may hurt the issue as well as the profession. And you may wander deeper into mistakes and lies. Media activity should therefore focus on agenda setting as it may generate important echo and snowball effects. If you have said something interesting about a certain topic, you are likely to receive more requests on the same topic during the next days, which will again generate further requests (snowball effect). It is also conceivable that the media will recall the coverage and your specific competence after a while and ask more questions on the same topic (echo effect). To be effective, it is important to replicate your position again and again, since it needs time and the right public attention to achieve your goal. Agenda setting is more satisfying in the long run than reactive media activity. It is easier for the independent scientist to turn down requests for reactive media work than for an economist at a research institute with a general advisory obligation.

4. You will need the courage to simplify. This applies especially to television and other mass media that focus more on the presentation than on the content. In my first nightmares as a media player, my economist colleagues kept appearing to me while I was giving television interviews. It makes no sense, however, to intellectually satisfy other economists when speaking to an audience of millions. 
5. In talk shows and roundtable discussions, a real scientist is always on the defensive end. Politicians and consultants have better knowledge of practical, supposedly descriptive details than economists, and they tend to know the single truth. These people convey their messages either short and crisp or long and boring - this is what they are trained to do every day. The academic culture of differentiation must step behind the consulting culture of simplification if you want to stand a chance as an economist. You will need to practice speaking loudly and interrupting others.

6. You should insist on examining interviews and citations before publication. This is an accepted practice at least in Germany. Not all journalists have the required expertise. Most texts will be short and condensed summaries of longer discussions that are likely distorted or simply wrong. Authorization not only protects you and the journalist from being seen as incompetent, but it also guarantees a high-quality product. It also happens, however, that journalists formulate better answers than you could have given yourself.

7. Symbioses with journalists can be advantageous for both sides. Here you can combine agenda setting with reactive media activities. The economist finds a journalist who conveys his messages. In return, the economist will be available for reactive media activities. Agenda setting allows the introduction of topics into the debate that may not have been published otherwise due to lack of interest. On the other hand, there is a danger that the economist becomes the journalist's instrument, if not his prostitute. The journalist will want radical statements because a provocative headline is always in high demand. If the economist comes to enjoy this, he is on the wrong track.

\section{$\underline{\text { 5. Conclusions }}$}

Economics is an empirical science. It is all about the interaction with data, facts, institutions and practical problems, and the need to control and improve societal and political processes. In the information age an exchange with the media is part of reality. But this exchange is not only the 
source of enjoyment and recognition; it can also serve to improve our own academic performance. If more of us were to fulfill their societal obligation to educate the nation in economic matters, we would have enhanced competition for quality that would improve political decisions and economic research. Hence, the risk of going wrong is smaller the stronger the profession. However, economists are not yet taught enough how to deal with the media. This is deplorable because media competence is learnable. 


\section{References}

Alston, R. M., J. R. Kearl and M. B. Vaughan. 1992. Is There a Consensus Among Economists in the 1990's? The American Review 82 (May): 203-209.

Blendon, R. J., J. M. Benson, M. Brodie, R. Morin, D. E. Altman, D. Gitterman, M. Brossard and M. James. 1997. Bridging the Gap Between the Public's and Economists' Views of the Economy. The Journal of Economic Perspectives 11 (Summer): 105-118.

Economist, The. 1997. The Puzzling Failure of Economics. The Economist (August): 13-14.

Economist, The. 2000. The Future of Economics. The Economist (March): 90-91.

Frey, B. S. 2000. Was bewirkt die Volkswirtschaftslehre? Perspektiven der Wirtschaftspolitik 1 (Februar): 5-33.

Frey, B. S. 2003. How Influential are Economists? Towards an Economics of Economics. mimeo., Institute of Empirical Economic Research, University of Zürich.

Fuchs, V. R., A. B. Krueger and J. M. Poterba. 1997. Why do Economists Disagree About Policy? The Roles of Beliefs About Parameters and Values. Princeton University: Industrial Relation Section, Working Paper No. 389 (August).

Medien Tenor. 2003a. Research Report No. 128 (15 January 2003).

Medien Tenor. 2003b. Research Report No. 132 (15 May 2003).

Rivlin, A. M. 1987. Economics and the Political Process. The American Economic Review 77 (March): 1-10.

Schelling, T. C. 1997. Why Does Economics Only Help with Easy Problems? In Economic Science and Practice: The Role of Academic Economists and Policy Makers, ed. P. A. G. van Bergeijk, A. L. Bovenberg, E. E.C. van Damme and J. van Sinderen. Cheltenham: Edgar Elgar.

Varian, H. R. 2003. How to Make a Scene. mimeo.

Weinstein, M. 1992. Economists and the Media. Journal of Economic Perspectives 6 (Summer): 73-77.

Wyplosz, C. 1999. The Culture of Economic Policy Advice: An International Comparison with Special Emphasis on Europe. In The Transfer of Economic Knowledge, ed. E. Mohr. Cheltenham: Edward Elgar.

Zimmermann, K. F. 2002. Frontiers in Economics. Berlin et al.: Springer.

Zimmermann, K. F. 2003. Reformen - jetzt! So geht es mit Deutschland wieder aufwärts. Wiesbaden: Gabler. 


\section{Appendix: Table A 1}

\section{European Economic Think Tanks (2002)}

\section{Germany}

DIW Berlin

Deutsches Institut für Wirtschaftsforschung

HWWA, Hamburg

Institut für Wirtschaftsforschung

Institut für Weltwirtschaft

Institut für Wirtschaftsforschung Halle

Forschungsinstitut zur Zukunft der Arbeit

Rheinisch-Westfälisches Institut für Wirtschaftsforschung

Zentrum für Europäische Wirtschaftsforschung

\section{Other European Countries}

IFS, UK

Institut for Fiscal Studies

NIESR, UK

The National Institute of Economic and Social Research

Observatoire Français des Conjonctures Économiques

IRS, Italy

Istituto per la Ricerca Sociale

CPB, Netherlands

Centraal Planbureau

Österreichisches Institut für Wirtschaftsforschung

Institut für Höhere Studien

Source: Homepages, Annual Reports, information of institutes. IfW, HWWA: without library 